\title{
EL VALOR MORAL DEL ARTE Y LA EMOCIÓN
}

\author{
Francisca Pérez Carreño \\ Departamento de Filosofía \\ Universidad de Murcia \\ fpc@um.es
}

RESUMEN: Frente al moralismo moderado, este ensayo defiende una forma de autonomismo moderado. Reconoce que en ocasiones la obra de arte excita emociones moralmente inadecuadas sin que ello impida su comprensión, y que esto podría contribuir a la clarificación de nuestra vida mental. El autonomismo moderado sostiene que el carácter autónomo de la obra de arte, representacional o ficcional, permite relajar nuestras exigencias morales. Sólo cuando la falsedad perjudica la verosimilitud se puede producir el fracaso de la obra: no por provocar emociones moralmente inadecuadas, sino al presentar como verdadero en la ficción algo falso o incoherente con la verdad en realidad.

PALABRAS CLAVE: moralismo, autonomismo, ficción, entendimiento

SUMMARY: Against moderate moralism, the essay defends a version of moderate autonomism. It claims that works of art sometimes provoke morally inadequate emotions without preventing the understanding of the work, and that they may serve to clarify mental life. Moderate autonomism holds that the autonomous nature of works of art, as representational or fictional, permits relaxing moral commitment. Only in case of falsehood obstructing verisimilitude, may the work fail, and then, not because of provoking morally wrong responses, but as a result of displaying as truth in fiction something plainly false or incoherent in life.

KEY WORDS: moralism, autonomism, fiction, understanding

Incluso los estetas más duros (un oxímoron evidente) pueden tener dudas sobre si la belleza o la forma significante son precisamente lo que el mundo necesita ahora, cuando otros bienes diferentes, como la inteligencia o la caridad, por ejemplo, serían más útiles para restaurar el sentido de la comunidad y detener la creación de una sociedad cuya respuesta a todos los problemas, estéticos o de otro tipo, es la represión violenta. [...] No es salvación lo que puedo ofrecer, sino algo más parecido a un caldo caliente.

(BEARDSLEY 1982, p. 77)*

\section{El arte y la moral}

En la discusión estética sobre la relación entre el arte y la moralidad existen dos posturas básicas: el moralismo, que mantiene la depen-

* Las traducciones de los textos originales son mías. 
dencia del arte respecto a la moral, y el autonomismo, que defiende la independencia de lo artístico y sus valores. A su vez, el moralismo ha sido entendido de modo diferente por dos concepciones opuestas del arte: utopista y platónica, según contemplen el arte como valioso o pernicioso desde el punto de vista moral. Si bien la defensa de la autonomía artística predomina desde el siglo XVIII hasta finales del XX, lo que mejor caracteriza al pensamiento moderno es la convivencia de una concepción autonomista de la práctica artística con el utopismo, la pretensión de la importancia social y moral del arte como instancia crítica y renovadora, cuando no revolucionaria. ${ }^{1}$

La Crítica del juicio kantiana marca el comienzo de la concepción autonomista, pero también de la concepción utopista del arte. A partir de la idea de que la belleza es "símbolo de la moralidad", 2 Schiller defiende que la auténtica autonomía moral del sujeto es resultado de su educación artística y que por eso el arte auténtico y elevado es moralmente valioso. Es preciso poner de relieve que, especialmente desde sus inicios románticos, el utopismo concede un lugar relevante del arte para la vida moral, pero que, al mismo tiempo, entiende que la justificación de la existencia del arte se encuentra en su finalidad ética. Naturalmente, los utopistas reconocen la existencia de obras sin valor moral, incluso perversas, pero que por ello son estéticamente defectuosas, al traicionar la propia finalidad que da sentido al arte. Según la concepción utópica, una buena obra de arte es moralmente valiosa, y las obras que no son moralmente buenas no son tampoco, por lo tanto, buenas obras de arte.

Cómo se realice la educación moral a través del arte es una cuestión que desde Schiller ha merecido atención, pero quizá sea en la concepción de la obra de arte como símbolo de un mundo moralmente deseable donde el carácter utópico de lo artístico se subraya con más claridad. Mediante la representación de un mundo diferente real, la obra de arte sugiere que "otro mundo es posible": un mundo más feliz, más justo, etc. De esta manera, las obras de arte construirían y presentarían mundos alternativos al real, facilitando la imaginación y la acción morales. ${ }^{3}$

${ }^{1}$ Cfr., por ejemplo, Menke-Eggers 1997.

${ }^{2}$ Kant $1790, \S 59$ y $§ 60$.

${ }^{3} \mathrm{Al}$ menos desde la Segunda Guerra Mundial, el utopismo negativo ha sido quizá la visión filosófica más poderosa. Puesto que, se ha dicho, la representación de mundos felices o sin conflictos puede servir tanto de figura utópica como de escape y consuelo, se sostiene que la obra moralmente valiosa es aquella que representa un mundo injusto, cruel o inmoral para provocar el disgusto y el rechazo estéticos, lo 
Un modo distinto de considerar la educación moral a través del arte consiste en hacerlo a través de la educación de los sentimientos morales. No sería tanto promoviendo actitudes o comportamientos, como provocando con las obras emociones que se consideran moralmente adecuadas, la forma en que el arte podría ayudar en la construcción de la moral. Se supone que el receptor de la obra de arte aprende y ejercita sus sentimientos morales frente a ella de un modo que, naturalizándose, será el que luego reproduzca en circunstancias reales similares.

Frente la concepción utópica, la concepción platónica del arte mantiene que el arte puede perjudicar, y a menudo lo hace, la moral individual y social. En la actualidad, las estéticas posmarxistas y postestructuralistas ejercen la crítica platónica sobre todo el arte moderno. Frente a la ingenuidad utopista, el platónico se rinde a la evidencia de que a lo largo de la historia las obra de arte no han sido siempre moralmente valiosas. Incluso lo han sido en pocas ocasiones y, lo que es peor, bajo la excusa moderna de su autonomía o excelencia esconden, justifican y sancionan puntos de vista inmorales e injustos. ${ }^{4}$ No podría ser de otro modo si, desde su punto de vista, la producción artística, como cualquier otro fenómeno social, está sujeta a las determinaciones y los intereses de la clase, la raza, el género o la geopolítica. Sirva como ejemplo un texto sobre la obra pictórica que se suele considerar el comienzo de la vanguardia clásica y, por ende, la cima de la autonomía artística:

Las señoritas de Aviñón persigue y recapitula la historia europea occidental del fantasma de la mujer-naturaleza hasta sus primeras hermanas históricas de Egipto, la antigua Europa y África para revelar su unidad. Sólo en el arte primitivo es la mujer tan infrahumana y tan superhumana como aquí. Muchas obras posteriores de Picasso, Miró o De Kooning recuerdan a esta madre-puta. Pero ninguna otra obra moderna revela más del fondo rocoso de antihumanismo sexista, o va más lejos y más hondo a la hora de justificar y celebrar la dominación de la mujer por el hombre. (Duncan 1993, p. 97)

que conduciría al rechazo moral y promovería un comportamiento crítico hacia la realidad injusta.

${ }^{4}$ En ocasiones, el platonismo se confunde con el utopismo negativo, aunque creo que de un modo injustificado, pues éste, si bien vacunado contra la ingenuidad de mantener que la representación artística conduce a la acción moral, todavía sostiene el predominio moral de la práctica artística vanguardista frente al resto de las actividades sociales, incluida la práctica política y la enseñanza ética. 
Pues bien, la primera consecuencia del moralismo en sus versiones utópica o platónica consiste en juzgar moral o políticamente las obras de arte, que han de ser valiosas éticamente. Se condena cualquier obra que no lo sea y se exige del arte que sea ético o político, que participe bien en la educación moral, bien en la acción política, como crítico o como propagandista, según le marque el filósofo. Frente al utopista, el platónico es mucho menos optimista sobre los beneficios morales del arte, pero como él considera que sólo cuando el arte contribuya a la vida moral estará justificado en su existencia. De esta funcionalidad ética de las obras de arte hacen derivar la idea de que el valor artístico más elevado consiste en satisfacer esa función. De ahí que para el moralista estético los valores morales de la obra contribuyan a (cuando no constituyan) su valor estético y, por lo tanto, los defectos morales perjudiquen su valor como obra de arte.

Frente al moralismo, para el autonomismo estético no es pertinente juzgar moralmente la obra de arte porque el arte es autónomo y sus valores son específicos. Lo que determina toda la discusión entre moralistas y autonomistas es que los primeros defienden que la función social del arte, su justificación, es de carácter ético, mientras que los autonomistas defienden que el arte no necesita justificación fuera de sí mismo. De ahí que aquellos defiendan que los valores morales son también propios del arte, en tanto que para los segundos sólo los estéticos lo sean. La polémica es de carácter metafísico mientras se mantenga en el nivel de la función social del arte, puesto que ni es empíricamente cierto que todas las obras de arte tienen interés moral, ni lo es que sólo posean valor en sí mismas.

La discusión filosófica sobre el autonomismo se centra en la definición de lo que sea el valor intrínseco del arte. Según la Crítica del juicio, el arte se justifica por la experiencia que proporciona, de placer desinteresado. La experiencia estética es valiosa (o tiene interés) en sí misma porque es placentera y porque el placer que brinda se debe al funcionamiento armonioso y libre de las facultades del espíritu. El arte bello, es decir, autónomo, proporciona esa experiencia y es por eso valioso. Pues bien, la autonomía de la experiencia o del placer estético se basa, en términos kantianos, en que el juicio estético es desinteresado, atiende a la que Kant llama la forma, pero no a la materia de la representación: juzga el modo en que nos representamos los objetos y los acontecimientos pero no los juzga en sí mismos, pues su existencia en realidad nos es indiferente. El juicio y el placer son, por ello, desinteresados: no son sobre el objeto, ni su utilidad, sino sobre su mera forma. Es difícil dar contenido a esta pretensión kantiana de desinterés, puesto que nuestras experiencias de objetos 
del mundo, como de obras de arte, lo son siempre de objetos y acontecimientos o de sus representaciones, de manera que no tiene mucho sentido decir que juzgamos la forma de una rosa, pero no en cuanto que de una rosa, o la composición de un edificio, pero no en cuanto que combinación de espacios, vanos, escaleras, columnas, etc., o de su utilidad. A pesar de estas dificultades, la concepción autonomista del arte ha insistido en el hecho de que las propiedades estéticas, es decir, aquellas sobre las que se realiza el juicio estético, son formales, en la medida en que se refieren a la composición, la coherencia, la integridad, la unidad, la proporción, y quizá también la intensidad y la expresividad, de la representación del objeto.

El argumento autonomista defiende el valor intrínseco de la obra de arte, pues lo es de propiedades intrínsecas de la representación, o de aquellas que posee en sí misma y no en relación con otra cosa. Ahora bien, interpretar de este modo la autonomía artística deja fuera del juicio estético todos aquellos aspectos referidos a las propiedades relacionales de la representación, por lo tanto, a su contenido, significado, expresión, etc., con lo que ello conlleva de empobrecimiento del juicio. Del mismo modo, también el juicio estético sobre la naturaleza se vería empobrecido si no tuviera en cuenta el contenido objetivo de la experiencia, por ejemplo, que se trate de la experiencia de un árbol, un peral o una secuoya.

Es posible entender de otro modo que los valores artísticos sean intrínsecos; a saber, que no sean instrumentales. En este sentido, Budd (1995) sostiene que "el valor artístico de una obra depende de sus cualidades estéticas, las cuales, a su vez, dependen de sus rasgos no estéticos" (p. 41), sean o no meramente formales. Entre estos rasgos no estéticos que son la base de los estéticos se encontrarían propiedades materiales o relacionales de la representación: como las representacionales o las expresivas, con tal de que esa representación o esa expresión no sean instrumento de algo distinto al disfrute de la obra, es decir, sean la base de cualidades estéticas. Si la experiencia de la obra es valiosa en sí misma y no sólo un medio para un fin ulterior, entonces hablamos de experiencia estética.

A pesar de la fuerza de los argumentos autonomistas a favor del carácter no instrumental del arte, lo cierto es que la mayoría de las obras sirven a otras funciones, además de la estética: no sólo las obras de arquitectura o de ingeniería poseen utilidad; también la música, la pintura o la escultura, por no decir, el cine o el cómic, pueden servir a intereses como el entretenimiento, el adorno, el recuerdo, la propaganda, etc. Ciñéndonos a la cuestión de la moralidad, incluso si 
la función del arte en la vida individual o social no es reducible a su función ética o política, es obvio que muchas obras de arte concretas sí tienen interés moral: encarnan opciones políticas, puntos de vista críticos o convencionales, o iluminan sobre conflictos éticos y políticos o sobre el sentido de la vida. Grandes obras de arte lo han hecho y seguramente entre sus valores se encuentra el que lo hayan hecho. Contra el autonomismo, lo cierto es que nuestras interpretaciones, experiencias, juicios y argumentos sobre las obras de arte se realizan, muchas veces, en términos morales, es decir, que damos razones morales para interpretar una obra y razones morales para evaluarla.

\section{El moralismo moderado}

Atendiendo este hecho innegable de nuestra relación con las obras de arte, Noël Carroll, entre otros, ha defendido lo que denomina un moralismo moderado, ${ }^{5}$ una opción más sofisticada y, sobre todo, más adecuada empíricamente, en defensa de cierto moralismo. Según Carroll, que ha estudiado en particular la narrativa, el arte posee valor moral porque contribuye a la "clarificación" de nuestras emociones y nuestro entendimiento moral. ${ }^{6} \mathrm{Su}$ interpretación moviliza nuestras creencias, sobre el mundo y morales, nuestras opiniones y emociones, que forman el trasfondo necesario para entender la obra. Además, el arte nos obliga a relacionar nuestras creencias, nos incita a aplicarlas a casos diferentes y a percibir las cosas desde diferentes perspectivas y según aspectos distintos del habitual: "no es el caso que las narraciones nos enseñen algo recién salido de fábrica, sino que más bien activan el conocimiento y las emociones, morales y de otro tipo, que ya poseíamos" (p. 282). Todo ello, aunque no aumente el número de nuestras creencias, contribuye a fortalecer nuestro entendimiento moral. Como decía Kant a propósito de la experiencia estética, aunque no proporcione conocimiento, nos hace sentir el libre juego de las facultades, nos obliga a ejercitar nuestra capacidad de juicio. El valor del arte consistiría pues en profundizar en aquello que ya sabemos y, sobre todo, en clarificar nuestro entendimiento, nuestra capacidad de juicio, moral. Si esto fuera así, según Carroll, sería posible realizar críticas morales al arte que fueran también juicios estéticos: serían malas obras de arte aquellas que "van en la dirección equivocada o confunden la crítica moral” (2001, p. 289), que conectan principios morales a particulares dudosos, o que "confunden más que aclaran" (p. 289). Aquellas obras de arte que sugieren movimientos del juicio

${ }^{5}$ Véase N. Carroll, "Moderate Moralism”, en Carroll 2001, pp. 293-305.

${ }^{6}$ N. Carroll, “Art, Narrative, and Moral Understanding”, en Carroll 2001, p. 283. 
(del entendimiento moral) contrarios a su propia naturaleza serían estéticamente fallidas. A pesar de la autonomía de la representación artística, habría un límite moral a lo que puede considerarse valioso estéticamente, de tal manera que: "algunas veces un defecto moral de una obra de arte puede contar como un defecto artístico" (Carroll 1998, p. 419). Éste es el llamado moralismo moderado.

Así como errores de tipo cognitivo, de incoherencia, de banalidad o de falsedad pueden resultar fallos de tipo estético, así también, cuando la obra no sólo no contribuye, sino que entorpece nuestro entendimiento moral, sus errores morales se convierten en estéticos. La razón de que estas obras moralmente defectuosas fracasen como arte es que impiden o perjudican una verdadera experiencia estética. Veamos muy brevemente cómo ocurre esto. Centrándose en las obras narrativas, Carroll considera que su interpretación consiste en la imaginación, en sentido amplio y complejo, de los hechos representados, supliendo el receptor el contexto necesario para darles sentido. En sentido amplio se entiende la actividad imaginativa como traer al pensamiento, visualizar, representarse ciertos hechos, tener expectativas con respecto a ellos o prever sus consecuencias, y también padecer los sentimientos, las emociones, los deseos, que les son adecuados. Ante la obra de arte, el intérprete se emplea en una tarea de colaboración imaginativa con el autor, en la que en lugar de considerar la verdad o falsedad de las representaciones, su valor informativo o ético, considera los hechos representados en su imaginación y reacciona emocionalmente hacia ellos.

Así pues, para entender una obra de arte movilizamos nuestras creencias sobre el mundo real, así como sobre el género o el estilo al que pertenece, y dentro de las creencias sobre el mundo se encuentran las de carácter moral. Entendemos, mientras no haya ninguna indicación en contra, que los hechos del mundo de la ficción obedecen a las mismas leyes físicas que el mundo real — como que el Sol sale por el Este-, las acciones a las mismas motivaciones - como que el orgullo impide reconocer los errores-, y que los objetos o acontecimientos reales poseen las mismas propiedades que en el mundo real —como que el Golden Gate está en San Francisco-. Del mismo modo, para entender la ficción mantenemos y utilizamos las mismas creencias morales, y valoramos éticamente los personajes, sus acciones y los sucesos en general como lo hacemos en la vida ordinaria.

Durante la interpretación de la obra también adoptamos creencias propias de la ficción. Entonces parece que adoptamos con mayor 
facilidad aquellas que se refieren a estados de cosas en el mundo de la ficción, aunque sean imposibles en el mundo real - por ejemplo, que los animales hablen, que haya saltos en el tiempo o que cabezas de alien salgan del estómago de una persona-, que las que suponen cambios en nuestras creencias morales — como que esté bien hacer daño, mentir o robar, o que un desengaño amoroso no sea doloroso - Esta circunstancia de la interpretación y la valoración artísticas, la resistencia de la imaginación, ya fue señalada por Hume en La norma del gusto: "Pero es necesario hacer un esfuerzo muy violento para cambiar nuestro juicio sobre los hábitos y provocar sentimientos de aprobación o rechazo, amor u odio, diferentes de los que la mente está habituada a desarrollar tras una larga costumbre" (1757, p. 50). No resulta fácil invertir el valor positivo o negativo que atribuimos a los hechos, aunque sea en la ficción. En buena medida, la razón es que la creencia moral implica una actitud afectiva hacia el hecho, "sentimientos de aprobación o rechazo", difícil de controlar a voluntad. Las respuestas afectivas provocadas o exigidas por la representación artística son, por el propio carácter de la interpretación y la comprensión artística, las mismas que en la vida ordinaria y la imaginación tal representación encuentra resistencias para modificar. Podemos imaginar, por ejemplo, un mundo en el que el infanticidio o deshacerse de los mayores no sean percibidos negativamente, lo que es difícil es que no percibamos esos actos como costumbres crueles e inmorales, que cambiemos la respuesta negativa que nos provocan.

Un defecto moral se convierte en un defecto estético, porque una obra moralmente defectuosa no moviliza las emociones necesarias para su interpretación y experimentación estéticas. Seguir la narración, prever las diferentes posibilidades de acción, enfocar la atención o las simpatías adecuadamente exigiría reacciones tan poco habituales que finalmente seríamos incapaces de entender la obra. Nuestra capacidad de juicio se vería incapacitada para seguir funcionando con corrección. Uno de los ejemplos que Carroll utiliza para explicar este fracaso en la comprensión de las obras de arte es la novela de Brett Easton Ellis, American Psycho, cuyo autor pretendía que fuera captada como una sátira política crítica de los años ochenta y que, por el contrario, causó desagrado entre sus lectores, los cuales no lograron captar irónicamente la violencia representada. No se trata de un fallo del público lector, sino del autor, que fracasó a la hora de crear un texto comprensible: el defecto moral se convirtió en un defecto artístico debido a la fuerte resistencia de la imaginación interpretativa por percibir los hechos bajo cierto aspecto. 
Así, el moralismo moderado parte del hecho de que compartimos creencias, sobre el mundo y morales, que utilizamos automática y necesariamente en la interpretación de las obras de arte. Ahora bien, a pesar del moralismo moderado, aunque compartimos principios morales, lo cierto es que, como el arte nos ha ayudado a percibir, el consenso en el juicio sobre hechos o comportamientos particulares es más difícil. Por ejemplo, es cierto que "robar" es un concepto cuya comprensión exige captar su valor negativo, pero no lo es que todas las acciones concretas de quitar un objeto a su dueño legal produzcan rechazo moral. Puede ser una cuestión analítica responder con rechazo ante lo que se considera que está mal, pero la dificultad es previa: está en la descripción, en la representación del hecho como un hecho malo. Es la misma representación la que induce una respuesta u otra, de tal manera que la valoración moral está ya implícita en la representación. Nuestra reacción emocional positiva sería correcta si la acción de despojar a alguien de su propiedad no se representara como un robo, sino como un reparto equitativo de la riqueza, por ejemplo, como sucede en Robin Hood.

Más aún, no sólo la representación de los hechos puede excitar una emoción quizá moralmente incorrecta, sino que la interpretación correcta de ciertas obras parece exigir, en ciertas ocasiones, puntos de vista morales directamente inadecuados. Para que la comprensión funcione sólo es necesario que el autor y el receptor compartan una perspectiva, o que el receptor identifique la perspectiva del autor y esté dispuesto a colaborar con ella adoptándola durante la interpretación. Es cierto que la aclaración de prejuicios morales puede ser mérito de una obra que suscitara respuestas emocionales adecuadas moralmente, pero no es necesario que sea así. Lo contrario también podría ser el caso. Por ejemplo, la literatura popular española nos proporciona numerosos ejemplos de estereotipos étnicos racistas. No parece que esta literatura pueda aclarar o iluminar errores morales, porque quizá esos errores sean necesarios para la interpretación correcta de la obra: hacen que se activen determinadas expectativas, se entiendan determinados comportamientos y quizá se justifiquen. Al menos en la época de su producción no suscitaban resistencia de la imaginación, sino, al contrario, los estereotipos facilitaban la interpretación. En ocasiones incluso la inmoralidad presentada o quizá defendida por un obra de arte pueden contribuir a su complejidad y su atractivo estético, no profundizando en nuestro conocimiento moral, sino precisamente poniéndolo en duda, llevándonos percibir conflictos, asociaciones, que permanecían ocultos a nuestra sabiduría moral. Los ejemplos se pueden multiplicar. 
De modo que la obra de arte podría sugerir la adopción de puntos de vista o la consideración de creencias inmorales. Pues bien, según el moralismo moderado, la resistencia imaginativa nos impediría adoptar estas actitudes moralmente perversas; ¿pero es así realmente? Es un hecho que en muchas ocasiones las emociones que experimentamos, correctamente desde el punto de vista de la interpretación, son de dudosa moralidad. Ciertas obras podrían "embarrar cuestiones éticas" sin que de ahí se siga que las emociones que promueven sean estéticamente inadecuadas, es decir, impidan una correcta comprensión. Géneros enteros como el melodrama o la novela negra están basados en la excitación de emociones inadecuadas o, cuando menos, faltas de proporción. La colaboración imaginativa del lector a menudo puede exigir poner en entredicho reacciones morales, o adoptar directamente actitudes inmorales sin que eso impida la comprensión de la obra; a veces incluso la facilita. Adviértase que esto es lo que preocupa a los platónicos: que nos sea relativamente fácil reaccionar inadecuada e inmoralmente, sin que por ello se resientan la comprensión, la verosimilitud o el éxito de la obra.

El citado texto de Hume prosigue así: "Y cuando un hombre confía en la rectitud del modelo moral por el cual juzga, lo defiende con justo celo, y no alterará los sentimientos de su corazón ni por un momento por complacer a escritor alguno" (1757, p. 50). En este fragmento, Hume se desliza de la imposibilidad de juzgar de modo diferente a la inmoralidad de hacerlo, es decir, a que sea posible aunque inmoral: "cuando un hombre confía $[\ldots]$ no alterará $[\ldots]$ " Todos nos hemos encontrado en esa situación en la que es posible utilizar la imaginación en sentido inmoral, captar el parecido humillante de una comparación, el chiste racista, o colaborar con el punto de vista sexista de un narrador. En ciertas ocasiones, hemos decidido colaborar en favor de la satisfacción estética o la exploración intelectual. En otras, hemos rehusado hacerlo, quizá para no colaborar en la creación de una imagen inmoral. Incluso es posible que en otros momentos haya habido una imposibilidad real de entendimiento, si no se han disparado las emociones previstas. Es decir, todas las circunstancias son posibles. Igual que Hume, Carroll parece deslizarse desde la resistencia a mantener imaginativamente ciertos principios inmorales a la denuncia de aquellos casos en los que, aunque no haya resistencia imaginativa, no deberíamos colaborar en la interpretación pretendida.

Lo cierto es que una vez comprometidos en la interpretación de una obra podemos reaccionar de un modo que no corresponda necesariamente a nuestro modo de ser o de pensar. Frente al moralista, 
el autonomista sostiene que no hay razón para no hacerlo. ¿Por qué habríamos de permitirnos imaginar que somos más aventureras de lo que somos, mucho más audaces, atractivas, inteligentes, y no más gamberras, más irresponsables o un poco sádicas? Adoptar imaginativamente un punto de vista heroico no nos hace más héroes, ¿por qué habría de hacernos moralmente peores adoptar el punto de vista del malvado? Para que la interpretación de la obra de arte sea correcta, nuestras respuestas han de ser congruentes con el punto de vista de la narración. Es preciso sintonizar con él y hacer una hipótesis sobre su intencionalidad: irónica, realista, gamberra, satírica, de denuncia política, aunque no siempre sea conveniente, seguro o moral hacerlo. A no ser que defendamos la ingenuidad imaginativa y moral, nos encontramos no ante una dificultad imaginativa, sino precisamente ante la posibilidad de adoptar creencias y puntos de vista diferentes de los ordinarios.

Esta llamada "paradoja" de la personalidad, que nos advierte cómo en la recepción de obras de arte imaginamos poseer creencias, emociones, deseos, diferentes de los propios, es una marca de la interpretación de ficciones. Por ejemplo, en las novelas de Patricia Highsmith, Tom Ripley es un marido enamorado, un gran aficionado al arte (y sus falsificaciones), un amante de los jardines y un sutil e inteligente ironista, y aun sabiendo que se trata de un criminal, nuestras simpatías están de su lado, de un modo que no deberíamos consentirnos en realidad. A mi modo de ver, lo que muestran las novelas de Highsmith es precisamente que podríamos sentir simpatía por el peor asesino sólo con que se mostrara inteligente y elegante. Al ponernos en esa situación, la ficción tiene una capacidad para iluminar nuestro comportamiento y aclarar nuestras emociones, pero precisamente mediante el funcionamiento inmoral de nuestro entendimiento. En todo caso, perjudicaría nuestra lectura que no nos dejáramos seducir por los encantos de Ripley, no nos dejáramos conducir por el humor negro de la narradora, o no percibiéramos el lado miserable de las víctimas de Ripley que, por otra parte, no se merecen en absoluto lo que les sucede. El lector de las novelas de Highsmith es testigo de actos de maldad y violencia sin que éstos le produzcan el desagrado que deberían causarle. Al lector sensible le pueden producir incomodidad, pero sobre todo le presentan algunos aspectos que la ética o la estética intelectualistas no se atreven a considerar. En contra del moralismo moderado, primero, esa aclaración se produce porque nuestras emociones funcionan de un modo poco o en absoluto moral. Y, segundo, tiene valor estético: contribuye a crear un universo complejo y sugerente bajo la apariencia de un mundo ordinario. 
Para el moralismo moderado, el error moral se produce cuando no rechazamos las emociones inmorales a las que invitan determinadas obras. Platónicos de todas las épocas se han enfrentado a la literatura por ello. El juicio contra Flaubert por Madame Bovary es un buen ejemplo. La novela de Flaubert nos invita a olvidarnos de la existencia de Charles, el marido de Emma, a favor de ella, representada como una persona mucho más compleja: joven, atractiva, con inquietudes, aunque sean banales y sentimentales. La acusación en el juicio era perfectamente razonable según los principios del moralismo moderado: el lector se veía conducido a realizar un juicio incorrecto, a percibir a una mujer adúltera como una heroína. En la acusación se señalaba que el libro debería haberse titulado Historia de los adulterios de una mujer de provincias (Pinard 1857, p. 480). Sin embargo, Madame Bovary es acusada de "ofensas a la moral pública y a la religión" no sólo ni básicamente por el tema (p. 475), sino por el modo en que Flaubert dibuja esos adulterios y promueve, por lo tanto, una incorrecta movilización de nuestro entendimiento: "La ofensa a la moral pública está en los cuadros lascivos que pondrá ante sus ojos; la ofensa a la moral religiosa, en las imágenes voluptuosas mezcladas con las cosas sagradas" (p. 480). A continuación, el acusador se detiene a citar, analizar y comentar fragmentos de la novela en los que efectivamente se dan a la imaginación (se ponen "ante los ojos") escenas eróticas y voluptuosas, incluso en circunstancias poco apropiadas como la extremaunción o la muerte de Emma. Aun si la intencionalidad de la obra hubiera sido didáctica: "una conclusión moral no podría amnistiar los detalles lascivos que se puedan encontrar en ella" (p. 498). ${ }^{7}$ Es decir, lo que la hace peligrosa no es tanto la moral que la obra defiende, como la imaginación inmoral que prescribe. Precisamente porque nuestro entendimiento moral funciona de modo incorrecto podemos disfrutar de la obra, al contrario de lo que Carroll supone al señalar que hay errores morales que entorpecen la experiencia.

En resumen, la crítica principal hacia el moralismo moderado consiste en que la comprensión de la obra de arte no siempre está en peligro por adoptar perspectivas inmorales. En ocasiones, la experiencia correcta de la obra exige que lo hagamos, y su valor estético en este caso puede incluso ser mayor que si no lo hiciéramos. Pasaríamos del moralismo moderado al platonismo si convirtiéramos la resistencia psicológica a responder inmoralmente en la prohibición

${ }^{7}$ Cfr. también Vargas Llosa 1974 sobre la novela de Flaubert y el disfrute en la violencia y el sentimentalismo.

Crítica, vol. 38, no. 114 (diciembre 2006) 
de hacerlo y, en consecuencia, condenaríamos Madame Bovary junto con tantas otras obras de arte.

\section{Moral e inteligibilidad}

El moralismo moderado considera principalmente aquellos errores que se deben a la excitación de emociones inadecuadas, porque es en este caso cuando nuestro entendimiento funciona de manera supuestamente incorrecta. Se trata de ocasiones en las que una percepción afectiva de un personaje o una situación impide aplicar correctamente una regla moral. Cuando la representación exige emociones inadecuadas moralmente y nuestro entendimiento moral se ve dominado por ellas, confundido, la obra es reprobable moral y estéticamente.

Como hemos visto, no es que Carroll piense que en la interpretación de las obras de arte debamos aplicar fríamente principios morales correctos. Al contrario, lo que nos obliga son las respuestas emocionales que la obra suscita, imprescindibles para una interpretación adecuada. Pues bien, en este punto el moralismo moderado podría descansar en una concepción estrecha de la relación entre emoción y moral. Según el cognitivismo que está en la base de la teoría de Carroll, el arte produce respuestas emocionales justificadas básicamente igual que en la vida ordinaria. Así, en el arte sentimos compasión por el héroe, que, por un error achacable a un carácter admirable en otras circunstancias, está a punto de sucumbir a un destino doloroso; sentimos inquietud por un personaje que se comporta dudosamente, indignación por su actitud despectiva hacia los demás, simpatía por sus torpezas, miedo ante una situación peligrosa, alivio cuando finalmente se deshace un malentendido, tensión, angustia, melancolía, en las mismas circunstancias que en la vida real. Estas emociones están justificadas por los juicios que nos hacemos sobre los personajes y el contexto, de tal manera que cuando la obra de arte busca la excitación de respuestas que no están justificadas por la representación se trata de una obra fallida. ${ }^{8}$ Desde el punto de vista de la experiencia estética, quien no siente compasión por el héroe no disfruta del placer propio de la tragedia; quien no sospecha del que parece el asesino no enfocará su atención hacia el lugar adecuado; quien no sufre por un malentendido no se sentirá aliviado cuando éste se resuelva, etc. Todas estas respuestas emocionales forman parte de una correcta interpretación y una experiencia adecuada de la obra de arte.

${ }^{8}$ Carroll 2002 ha defendido con razón que juzgamos a los personajes de ficción según los mismos criterios que usamos para las personas reales. 
Hasta aquí el modelo de emoción parece correcto. Es un modelo cognitivista que se reconoce heredero de Aristóteles y, según el cual, si la obra no proporciona las experiencias para las que fue creada, es una obra fallida. Por esta razón, un defecto moral, que exige una emoción inapropiada, puede o bien no lograr hacer que surja, o bien obtenerla, pero injustificadamente. El modo en que las obras de arte aclaran el entendimiento moral, según Carroll, es precisamente mediante la profundización en nuestro entendimiento emocional: "como podría decir Aristóteles, porque nos enseñan a traer la emoción adecuada a un objeto adecuado con la intensidad apropiada". 9

Ahora bien, para Carroll la justificación de una emoción parece exigir algo que no creo que sea realista exigir y que no estaba presente en las explicaciones de Aristóteles ni de la Poética ni de la Retórica, a saber, la convergencia de entendimiento moral y entendimiento emocional. Pensar que ambos coinciden es sólo optimismo injustificado. Las emociones no tienen por qué ser moralmente adecuadas para ser emociones justificables, es decir, adecuadas y proporcionales, ni en la vida ni en el arte. Carroll parte del modelo aristotélico, pero lo intelectualiza en exceso. Insiste en que nuestras emociones no son irracionales o arbitrarias, y es cierto que no lo son, pero tampoco son racionales en el sentido de independientes de factores individuales, ni son racionales en el sentido de totalmente previsibles (deducibles) a partir de una situación dada. Tampoco obedecen necesariamente a normas morales. Por esa razón, no son sólo razones morales las que explican nuestra actitud hacia el héroe, por ejemplo. Al menos el héroe trágico es admirable por la grandeza de sus acciones y de su carácter, y eso es moralmente bueno, pero también es admirable por el modo en que, por un exceso de hybris, que es inmoral, encuentra su destino trágico. Y eso provoca simpatía en el espectador, compasión hacia él. Es cierto, como recuerda Carroll, que el héroe no debe ser "un malvado" (2001, p. 301), porque si lo fuera se merecería lo que le sucede y no podríamos sentir pena por él. Esto es analítico según la definición aristotélica y también parece adecuado psicológicamente, pero la representación de una persona que no actúa según un principio moral puede no ser la de un malvado. El héroe es digno de compasión porque entendemos que, dado su carácter, al que pertenece una impía hybris, el error que le conduce al destino trágico es comprensible, aunque sea inmoral. Por eso "no se merece" el destino que le espera; no porque no sea responsable moral de su

\footnotetext{
${ }^{9}$ Véase Carroll, “Moderate Moralism”, en Carroll 2001, p. 300.
} 
acción, que lo es, sino porque es inteligible que haya actuado así. No necesario, pero sí probable.

Entendemos las razones de los personajes de una ficción, incluidas las del narrador, precisamente desde su punto de vista que es, por necesidad, subjetivo. Sólo nos compadecemos de Edipo o de Lear porque son admirables también en sus errores y en sus defectos de carácter. Por eso, de las acciones de los personajes no esperamos que sean morales, sino inteligibles. Del mismo modo, nuestras respuestas ante la ficción pueden no ser correctas moralmente sino, digamos, emocionalmente. La inteligibilidad de las acciones humanas es básicamente resultado de la interacción de deseos, creencias y emociones, pero el arte nos las muestra frecuentemente como resultado de emociones inapropiadas, de deseos insensatos y de creencias que no podemos compartir, de la debilidad de la voluntad, etc. Y lo hace utilizando puntos de vista que también están sujetos a estas circunstancias. Nuestro juicio no es moral sino estético, juzga las acciones de los personajes por su inteligibilidad, o según el concepto aristotélico, su verosimilitud, es decir, su probabilidad. Paradójicamente, es el carácter probable de la acción lo que garantiza la libertad, esto es, la capacidad moral del personaje, la base para que lo juzguemos moralmente, aun cuando no lo hagamos. La experiencia estética es emocionalmente sensible y es correcta si las emociones son adecuadas a la representación, es decir, si son adecuadas a representaciones inteligibles, coherentes y verosímiles, pero no necesariamente morales.

Ahora bien, es cierto que es un defecto de la obra no hacer inteligibles las acciones de los personajes, no dar coherencia, necesidad y probabilidad a los hechos. Pero no diría que un defecto que impide la comprensión de los actos o los sucesos sea un defecto moral, sino cognitivo, que, ahora sí, es al mismo tiempo un defecto estético. Por esta razón, la obra también puede ser moralmente defectuosa, pero sobre todo lo es cognitiva y estéticamente. El fallo de Easton Ellis en American Psycho no es moral. El autor ha fracasado a la hora de transmitir el tono irónico y crítico hacia los años ochenta y ha creado, al contrario, una novela que es emblema de la posmodernidad nihilista. Su error ha sido primeramente estético porque no ha dotado a los hechos representados de la coherencia necesaria y de la perspectiva adecuada para hacerlos inteligibles, porque no ha hecho posible que los lectores perciban "los asesinatos como sátira política" (Carroll 2001, p. 302). Los lectores o no han percibido la sátira o no han obviado la inmoralidad para disfrutar de la sátira; es decir, han reaccionado adecuadamente con rechazo. La cuestión es que, ante una buena construcción novelesca, es probable que un lector moralmente 
sensible reaccionara ante los asesinatos sin rechazo. Que Ellis no lo haya logrado puede deberse a una simple falta de habilidad.

Según una concepción cognitivista de las emociones, la emoción contiene un elemento cognitivo, una creencia sobre el objeto hacia el que se dirige, que la explica y justifica. Carroll introduce, en este modelo cognitivo básico, la matización de que el elemento cognitivo implícito en la emoción en los contextos de ficción no es una creencia, sino un pensamiento, ${ }^{10}$ es decir, una proposición que no es aseverada, ni afirmada ni negada, sino meramente mantenida ante la mente. Además, junto al elemento cognitivo presente en la emoción, una actitud afectiva debe pertenecer a su intencionalidad. ${ }^{11}$ Nada surge de la representación neutral de los hechos; es preciso un punto de vista subjetivo, una actitud afectiva hacia ellos, para entender las emociones que provocan. Esta actitud, que pertenece al sujeto de la representación, incorpora los motivos de actitudes preferenciales que quizá no sean morales, y ni siquiera estén justificadas, pero que sean inteligibles. Este hecho es especialmente relevante en el arte, y en narraciones visuales como el cine, en el que no sólo las acciones o los hechos representados, sino la escenografía, la fotografía o la mera presencia física de los actores sugieren emociones de aprobación o rechazo por la actitud preferencial hacia el objeto. En una película de interés ético como Dogville, de Lars Von Trier, parte de las respuestas emocionales se deben a la mera presencia física de Nicole Kidman en el papel de Grace. Su belleza, su palidez, su cabello rubio, su gesto etéreo, su aire misterioso producen, desde el principio, sentimientos favorables hacia ella. La belleza de Nicole Kidman/Grace, y el modo en que es representada fílmicamente sirven para fijar nuestra atención, excitar nuestras simpatías hacia ella y levantar expectativas sobre la trama. Las emociones que provocan los acontecimientos en los que se ve inmersa son explicables en parte por estas preferencias afectivas, sin que sea necesario elaborar creencias sobre esas características físicas del personaje.

El principio de racionalidad no puede ser tan estrecho como para esperar que la percepción de los hechos que explica nuestra emoción sea estrictamente moral. Trasladar un modelo intelectualista de las emociones a la obra de arte no sirve para explicarla mejor. Quizá haya algo que aprender de la naturaleza de las emociones desde el

\footnotetext{
${ }^{10}$ Se trata de una postura extendida entre los teóricos de las emociones en la ficción. Cfr., por ejemplo, Olsen y Lamarque 1994.

${ }^{11}$ Entre los principales defensores de un elemento afectivo en el núcleo de la emoción se encuentran Wollheim 1999 y Goldie 2000.
} 
arte; por ejemplo, sobre la insuficiencia de un modelo cognitivista que no incluya un elemento afectivo, o no considere la diferencia entre imagen y lenguaje o la importancia del modo de presentación. Las imágenes ponen de manifiesto la extrema sensibilidad de las emociones al modo de representación del objeto, y la narración, la compleja estructura de las emociones.

Así, aunque la relación entre el arte y la moralidad tenga que ver con la clarificación del entendimiento moral a través de las emociones, Carroll falla al utilizar un modelo sencillo aristotélico y mezclarlo con un modelo ético-estético kantiano. Quizá la clarificación que el arte nos proporciona, en relación con la moral, se refiera a su origen, más que a la moralidad en sí misma. Esto obedece sencillamente a que, para que el juicio estético sirva de puente entre el conocimiento y la moral, lo que es deseable debe serlo universalmente, pero el arte representa necesariamente puntos de vista individuales, lo que por otra parte es necesario para explicar nuestras emociones, incluso algunas de las consideradas morales. La comprensión de la obra de arte no exige que lo representado como deseable lo sea universalmente, sino que, al contrario, considera lo que de hecho es deseable desde los puntos de vista contenidos en la representación y de la propia representación. Los diferentes deseos, ansias, aspiraciones y creencias que están en el fondo de las acciones humanas son la materia prima del juicio; seguramente son, además, tan comprensibles (a veces no) como imposibles de mantener desde nuestra posición en la vida real, lo cual es una de las principales enseñanzas de la ficción.

\section{Autonomismo moderado}

Las obras de arte poseen valores de diferente tipo: utilitario, político, moral, de entretenimiento, etc. Frente a quienes consideran que su autonomía consiste en la posesión de un valor intrínseco, es decir, el de sus propiedades puramente formales o no instrumentales, creo que la autonomía del arte consiste en su carácter representacional o ficticio. ${ }^{12}$ Una obra de arte representa, sin comprometerse con su verdad, estados de cosas y acontecimientos. Es decir, tal y como lo entiendo, una obra de arte representa, mediante diversos medios, objetos, estados de cosas y acciones o, lo que es lo mismo, finge que ciertos objetos están presentes, que ocurren ciertas cosas o que se están realizando ciertas acciones. A pesar de su falta de compromiso directo con la verdad de lo representado, las obras de arte pueden

\footnotetext{
${ }^{12}$ En el sentido de Beardsley 1981, 1982.
} 
poseer valor cognitivo y ético, pues entender la autonomía del arte en relación con su carácter representacional no impide considerar que las obras de arte particulares respondan a muy diferentes fines sociales o individuales. En sentido contrario, que cumplan funciones cognitivas, sociales, etc., tampoco significa que sea imposible tener una experiencia estética de ellas.

Junto a su carácter representacional, la obra de arte posee otros atributos, pero además, precisamente a través de su carácter representacional puede servir a otras funciones. Como defienden los moralistas, los valores morales junto a otros de carácter cognitivo o puramente formal son parte de los valores de la obra considerada de manera global. Entre los méritos morales de ciertas obras de arte se encuentra su poder para eliminar prejuicios, cambiar una manera inmoral de percibir las cosas en favor de otra justa, clarificar emociones, explorar en profundidad el mundo emocional y mental o exponer situaciones complicadas moralmente o conflictos entre valores. Ahora bien, cuando el mérito moral de una obra tiene que ver con la forma de la representación y cuando sus logros morales son el resultado de méritos que llamaríamos estéticos, es cuando se trata propiamente de su valor moral como obra de arte. Es su capacidad para provocar juicios reflexionantes, es decir, para dirigir la atención sobre nuestras propias ideas y sentimientos, lo que produce clarificación y autoconocimiento. Por eso, cuando la obra posee valor moral, el éxito es mayor si su producción no está constreñida por principios morales, ni dirigida a la transmisión de esos principios, sino cuando se dirige a la imaginación libre, aunque sea poniendo a aquéllos en peligro.

Los juicios de conocimiento y los juicios prácticos consideran la verdad o falsedad, la adecuación o no de una representación a su objeto, mientras que el estético considera la representación y su contenido en cuanto a su coherencia, su capacidad de sugestión de imágenes, emociones, o ideas, su integridad y su intensidad. Más que en la particularización de una verdad sabida, o en la ilustración de un principio ético, el valor moral de un obra residiría en su capacidad de sorprender, de atrapar al espectador sensible en la imaginación y la reflexión o el juicio de estados de cosas quizá de dudosa categorización ética. La diferencia entre juzgar algo como bueno o malo, verdadero o falso o, por el contrario, verosímil, novedoso o banal, es la que se da entre interpretar una representación y un género verídico. Cuando interpretamos obras de arte participamos en actividades comunicativas en las que la actitud correcta es la de imaginar, hacer las suposiciones precisas e involucrarnos afectivamente en la narración, la imagen o el sonido. Juzgamos, en primer lugar, sobre su capacidad para hacerlo. 
Comprender una obra de arte consiste principalmente en experimentarla correcta y completamente, es decir, en colaborar en la creación de los pensamientos, sentimientos, y aquellos estados mentales que la representación de los hechos exige. En este sentido, no parece existir ninguna diferencia en lo que se refiere a las reacciones afectivas y morales ante la ficción y la realidad, de ahí la importancia del arte para la vida. La comprensión lingüística, la percepción de objetos o de material sonoro, así como las respuestas afectivas que les son adecuadas, son del mismo tipo que la comprensión y la percepción en circunstancias ordinarias; básicamente cumplen las mismas funciones. En particular, las emociones colorean nuestra visión del mundo, hacen que fijemos la atención en un lugar, una persona o una propiedad de los objetos o acontecimientos y nos colocan con una determinada actitud frente al mundo. En ambos casos, esa reacción depende en parte del modo de presentación del contenido — visual o lingüístico, realista o de ficción, etc.-, y está influida por la perspectiva de la representación, que normalmente tiene carácter afectivo. Cuando se trata de una obra de arte, este hecho cobra una relevancia especial hasta el punto de que los valores estéticos son previos a su valor moral o de cualquier otro tipo. El arte posee valor moral como resultado de su éxito como representación y precisamente por eso es más valioso — en ocasiones, más peligroso - moralmente. El valor que para el utopismo estético posee la obra de arte descansa en la idea del poder del arte para evocar emociones e ideas que no dependen de su verdad, sino de cualidades como su complejidad, su atractivo, su interés, su originalidad, su intensidad o su integridad, que son cualidades estéticas. Sin embargo, ese poder no es sólo la facultad de crear símbolos morales, sino también sus opuestos.

Es necesario, si el moralismo quiere ser una opción interesante para la filosofía del arte, que el valor moral de la obra se base en méritos artísticos y estéticos en particular. Es cierto que en ocasiones el valor moral de una obra descansa en sus méritos estéticos; pero, como vimos en la sección 2 de este ensayo, esto no implica que ciertos defectos morales perjudiquen la creación de una obra valiosa estéticamente. En especial, la falta de claridad ética puede ser fruto de su complejidad estética.

Para finalizar, quisiera exponer un límite de la autonomía estética que, por analogía con el moralismo moderado, describiré como el hecho de que, en algunas obras de arte, los errores cognitivos son también errores estéticos. Entre estos errores cognitivos se hallan algunos de carácter moral que se suceden necesariamente de los primeros. El autonomismo moderado parte de la premisa kantiana de 
que, en el juicio estético, la imaginación actúa libre, pero no de forma caprichosa, es decir, no en contra de sus propias reglas de funcionamiento. El autonomismo moderado que propongo reconoce, no obstante, otros límites a la imaginación, lo que explicaría fenómenos como el de la resistencia imaginativa. Son límites que tienen que ver con la falsedad de la representación de los hechos cuando provocan la inverosimilitud de la representación artística. ${ }^{13}$

El carácter ficticio (representacional) de las obras de arte justifica que respuestas que serían inmorales en la vida ordinaria no lo sean en la interpretación artística. La autonomía estética es una marca de las obras de arte que, como representaciones, son liberadas de la consideración de la verdad o falsedad de su contenido. Las emociones poseen, como sostiene Carroll, la misma estructura en la ficción y en la realidad; en ambos casos, su estructura es más compleja que la mera adecuación a ciertas creencias o pensamientos, e incluye actitudes afectivas promovidas por el tipo de representación, por expectativas ordinarias o por propiedades de los objetos independientes de las consideradas por las creencias o los pensamientos que justifican la emoción. Así, el hecho de que en la interpretación de obras de arte no se considere la verdad o la falsedad de la representación explica que no se mantengan las exigencias cognitivas y morales de lo real.

Supongamos el caso de dos representaciones idénticas, es decir, que posean el mismo contenido y la misma forma. Las respuestas afectivas que provocarán serán distintas en el caso de que se trate de representaciones de realidad, verdaderas o falsas, y en el caso de que se trate de ficciones (de representaciones artísticas). Esto significa que ni el contenido ni el modo de representación determinan completamente las respuestas adecuadas, pero el propio carácter, verídico o de ficción, puede marcar la diferencia. Por ejemplo, algunas imágenes de los atentados del 11-S de dos aviones chocando contra las torres del World Trade Center son iguales a otras imágenes que circulaban antes del atentado - por lo tanto, de carácter ficticio-. El contenido de las imágenes es idéntico y el medio de presentación,

\footnotetext{
${ }^{13}$ Durante la elaboración de este ensayo apareció el artículo de Stecker 2005, que propone una versión parecida de la relación entre arte y moralidad. Según Stecker, la inmoralidad de la ficción representa un impedimento para la experiencia estética dependiendo de la cercanía de lo representado con lo real. Cuando se trata de géneros realistas, la resistencia imaginativa es mayor si el mundo de la ficción en el que se violan los principios morales es más cercano temporalmente al nuestro, mientras que se debilita cuando se trata de mundos temporalmente alejados, como el de la Grecia antigua, por ejemplo.
} 
la espectacularidad y su intensidad visual también. Lo único que varía es el hecho de que se trata de imágenes reales en un caso y de ficción en otro. Pues bien, el simple conocimiento de que se trata de ficción o de realidad marca la diferencia con respecto a la repuesta: no es algo interno, el contenido o la forma de la representación, lo que explica por completo nuestra respuesta en un caso o en otro. Las representaciones pueden no mostrar marcas gramaticales o semánticas de ficcionalidad. Las diferencias, cruciales, son por lo tanto de carácter pragmático, no semántico.

Es inmoral juzgar estéticamente acontecimientos o representaciones verídicas de acontecimientos, como lo es estetizar la política; es decir, es inmoral juzgarlos sin atender a su verdad o falsedad. En el caso de las obras de arte nos colocamos en otra situación, el conocimiento de que se trata de ficción, que no cambia la estructura de nuestras operaciones mentales, pero sí su estatus. El carácter representacional de la obra de arte nos permite interpretarla sin limitar nuestras respuestas por ataduras morales; podemos admirar la belleza siniestra, y la espectacularidad de la guerra, podemos atender a todas las consideraciones que hacen de un asesinato o de un atraco una obra de arte, etc., en ocasiones por puro entretenimiento o, en otras, porque eso nos permite explorar los rincones oscuros de nuestra naturaleza, percibir relaciones o perspectivas insospechadas, o investigar conflictos entre creencias y normas.

Así, en la ficción podemos permitirnos licencias que no son apropiadas frente a lo real. La forma artística de la representación, su carácter realista o fantástico, el género artístico pueden implicar, como hemos visto, no sólo que movilicemos las creencias o las emociones adecuadas al contenido, sino también que adoptemos, durante el tiempo de la ficción, personalidades que no nos pertenecen. No es preciso ser un cotilla para interesarse por las novelas de Jane Austen, ni hace falta ser un militarista para disfrutar del cine bélico, ni creer que la amistad es más valiosa que el deber ético para disfrutar de Forster o, al contrario, para admirar a Greene.

La autonomía del arte es la que le proporciona su naturaleza representacional, la que favorece una experiencia que no está limitada por las ataduras de la verdad, lo cual no significa que las relaciones entre el arte y lo real o la verdad sean por ello simples. El autonomismo moderado presta atención a aquellos momentos en los que la verosimilitud artística se ve perjudicada por la falsedad de la representación. Si los límites entre la realidad y la ficción son porosos, como sin duda lo son, entonces en algunas ocasiones la realidad penetra en el mundo de la ficción de un modo que no se puede obviar. 
En primer lugar, que una representación sea una ficción no significa que no sea también verdadera o falsa en el mundo real, en parte o globalmente. Por un lado, durante la interpretación se mantiene la veracidad de creencias de carácter general, pero también de las existenciales: Londres sigue siendo la capital del Reino Unido, es atravesada por el Támesis y a veces se cubre de niebla durante el invierno. Estos hechos pueden ser cruciales en una obra y, como hemos visto, el mero conocimiento de que el contenido es real hará que varíen nuestras respuestas hacia la representación, aunque sea artística. Obviamente, la primera consecuencia de ello es que el efecto de realidad de la representación se ve favorecido. La diferencia de actitud frente a lo real o lo inventado se utiliza legítimamente tanto en los relatos ficticios que se dicen "reales" o "basados en la realidad", como en los documentales, etc., de carácter artístico. ${ }^{14}$ En ambos casos se intenta debilitar la diferencia entre ficción y realidad en beneficio de la verosimilitud, en el primer caso, y de la intensidad de la representación y la capacidad de compromiso del espectador en el segundo.

Algunas imágenes previas a los atentados terroristas del 11-S han resultado ser tan verdaderas como las que se grabaron de los sucesos reales. Ahora bien, una vez que se conoce que el contenido de la ficción es verdadero, considerar la representación como mera representación provoca rechazo. Esta situación se puede generalizar a todas las representaciones artísticas: la estrecha relación entre ficción y realidad se debe en parte al hecho de que las representaciones artísticas exigen, para su comprensión, la movilización de nuestro acervo cognitivo completo, de muchas de nuestras creencias referidas a personas, hechos históricos, o sucesos concretos reales. Cuando eso sucede, la verosimilitud de la representación está sujeta a los constreñimientos de la verdad: entonces ciertos hechos sólo serán verosímiles si son verdaderos o coherentes con la verdad. No es verosímil que el personaje de Hitler sea de carácter bondadoso, sencillamente porque no es verdad que Hitler lo haya sido. Por eso, la discusión crítica de El hundimiento, basada en sus últimos días en el búnker de Berlín, se centró en si el personaje estaba demasiado humanizado. Cuando la ficción incorpora personajes o situaciones reales, la coherencia interna no es suficiente para garantizar la verosimilitud, en consecuencia, el valor estético de la obra. La falsedad de aquello que se representa,

\footnotetext{
${ }^{14}$ La diferencia es reconocida y apreciada ilegalmente también por los aficionados a las snuff movies.
} 
la falta de fidelidad histórica, por ejemplo, pueden ser la causa de su falta de verosimilitud.

Del mismo modo, las emociones provocadas por representaciones inverosímiles serán inadecuadas. Quizá se trate entonces de respuestas inmorales o fallos del entendimiento moral, pero están provocados por un error estético previo: la inverosimilitud. Por eso se trata de una postura autonomista. Sólo cuando la falsedad o la inmoralidad perjudican la verosimilitud de la representación se produce un fallo estético y este fallo es el que marca los límites a la imaginación. Mientras los límites estén claros no tiene sentido hablar de embarrar el entendimiento moral o enturbiar en vez de aclarar. El intérprete de la ficción puede permitirse responder del modo en que el autor haya previsto, puesto que sabe que este ejercicio de su imaginación es distinto al ejercicio del juicio en la vida ordinaria. Obviamente, los límites no suelen estar claros, pero entonces la discusión se establece en el terreno de la crítica y no de la estética o de la moral. La polémica sobre el cine de Tarantino, por ejemplo, no puede saldarse en el terreno de la filosofía del arte, como quisiera Carroll al mantener que "embarra sobre cuestiones morales", sino en el de la crítica cinematográfica, porque es en el terreno de la crítica donde se puede establecer si las emociones presuntamente inmorales que provoca surgen de la aplicación incorrecta de principios morales o, por el contrario, de otras propiedades de la representación. Es obvio que la ficción se utiliza a menudo como vehículo de creencias inadecuadas o inmorales, pero sólo la interpretación y la crítica inteligentes han de servir de freno a pretensiones falsas e inmorales que convierten a la obra en inverosímil e ineficaz. ${ }^{15}$

\section{BIBLIOGRAFÍA}

Beardsley, Monroe, 1982, The Aesthetic Point of View, Cornell University Press, Londres.

—_, 1981, "Fiction as Representation", Synthese, vol. 46, pp. 291-314.

\footnotetext{
${ }^{15}$ Este trabajo forma parte de los proyectos de investigación financiados por el Ministerio de Educación español: "El papel de la voluntad en la formación de creencias y los juicios de gusto" y "La expresión de la subjetividad en las artes". Versiones anteriores fueron leídas en el seminario “¿Hace Justicia el Arte?”, celebrado en la Universidad Pompeu Fabra de Barcelona, el 23 de mayo de 2005, y en el Seminário de Filosofia Analitica de la Universidad de Lisboa, el 16 de diciembre de 2005. Agradezco los comentarios y sugerencias de ambas audiencias. También estoy en deuda con María José Alcaraz, Valeriano Bozal, Jordi Ibáñez y un árbitro anónimo de Crítica, por sus observaciones al texto.
} 
Budd, Malcolm, 1995, Values of Art: Pictures, Poetry and Music, Penguin, Londres.

Carroll, Noël, 2002, "The Wheel of Virtue: Art, Literature and Moral Knowledge", The Journal of Aesthetics and Art Criticism, vol. 60, no. 1, pp. 3-26.

——, 2001, Beyond Aesthetics, Cambridge University Press, Nueva York. -, 1998, "Moderate Moralism vs. Moderate Autonomism", British Journal of Aesthetics, vol. 38, no. 4, pp. 419-424.

Duncan, Carol, 1993, "Virility and Domination in Early 20th Century Vanguard Painting", The Aesthetics of Power, Cambridge University Press, Cambridge, pp. 81-108.

Goldie, Peter, 2000, The Emotions. A Philosophical Exploration, Clarendon Press, Oxford.

Hume, David, 1757 (1989), La norma del gusto, trad. María T. Beguiristáin, Península, Barcelona.

Kant, Immanuel, 1790 (1977), Crítica del juicio, trad. Manuel García Morente, Espasa-Calpe, Madrid.

Menke-Eggers, Christoph, 1997, La soberanía del arte, trad. R.S.O. de Urbina, Visor, Madrid.

Olsen, Stein Haugom y Peter Lamarque, 1994, Truth, Fiction and Literature, Clarendon Press, Oxford.

Pinard, E., 1857, "Réquisitoire", en "Le procès de Madame Bovary", en G. Flaubert 1856 (1972), Madame Bovary, ed. Maurice Nadeau, Gallimard, París.

Stecker, Robert, 2005, "The Interaction of Ethical and Aesthetical Value", The British Journal of Aesthetics, vol. 45, no. 2, pp. 138-150.

Vargas Llosa, Mario, 1974, "Una pasión no correspondida", en G. Flaubert, Madame Bovary, trad. Consuelo Berges, Alianza, Madrid.

Wollheim, Richard, 1999, On the Emotions, Yale University Press, New Haven.

Recibido el 30 de septiembre de 2005; revisado el 2 de septiembre de 2006; aceptado el 4 de octubre de 2006. 